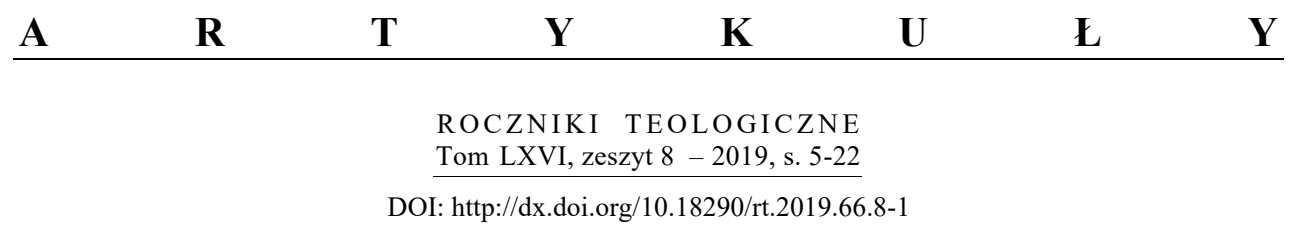

KS. WALDEMAR BARTOCHA

NAŁOŻENIE RĄK W LITURGII ŚWIĘCEŃ

W PIERWSZYM TYSIĄCLECIU

(CZESŚĆ I: STAROŻYTNOŚĆ CHRZEŚCIJAŃSKA)

\author{
IMPOSITION OF HANDS IN THE LITURGY OF HOLY ORDERS \\ IN THE FIRST MILLENNIUM \\ (PART ONE: CHRISTIAN ANTIQUITY)
}

\begin{abstract}
A b stract. Imposition of hands belongs to the essence of the ordination rites of bishops, presbyters and deacons, beside the ordination prayer itself. This gesture occurs in close correlation with the ordination prayer which follows it. The prayer of blessing and petition determines its meaning. The post-conciliar liturgical reform of the rites of ordination emphasized the rite of imposition of hands, thus restoring its original meaning. The aim of this article is to show the origin and theological meaning of the gesture of imposition of hands, as well as its place in the structure of ordination celebrations in the first millennium. The gesture of imposition of hands has biblical roots. In the New Testament, placing hands on a candidate meant imparting to him the charism appropriate to the office. In the ritual schema contained in the apostolic Tradition, the gesture of laying on of hands is used to entrust the office of bishop, presbyter and deacon. It plays a central role in the dynamics of the celebration of Holy Orders.
\end{abstract}

Key words: imposition (laying on) of hands; ordination; Holy Spirit; bishop; presbyter, deacon.

We wprowadzeniu ogólnym do drugiego wzorcowego wydania Obrzędów święceń biskupa, prezbiterów i diakonów wyraźnie zaznacza się, że „nałożenie rąk i modlitwa święceń stanowią istotny element każdych święceń, przy czym modlitwa błogosławieństwa i prośby określa znaczenie nałożenia

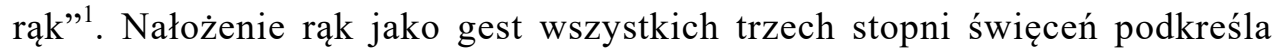

Ks. dr WALDEMAR BARTOCHA - Uniwersytet Kardynała Stefana Wyszyńskiego, Wydział Teologiczny, Katedra Teologii Liturgii, adiunkt; adres do korespondencji - e-mail: waldek bartocha@poczta.onet.pl

${ }^{1}$ Pontyfikat Rzymski. Obrzędy święceń biskupa, prezbiterów i diakonów [odtąd OŚBPD], Katowice: Księgarnia św. Jacka 1999, nr 7, s. 13. 
ich ontyczną jedność ${ }^{2}$ oraz w połączeniu z modlitwą święceń staje się swoistym pasem transmisyjnym w procesie przekazu Ducha Świętego i jego darów odpowiednio do posługi, do której kandydat jest wyświęcany (por. KKK 1573). Przy każdych święceniach gest nałożenia rąk wykonywany jest w milczeniu i przybiera inny wariant, angażując różne kręgi współdziałających w centralnym i szczytowym momencie celebracji. Na biskupa elekta ręce nakładają wszyscy biskupi, gdyż jest on włączany do Kolegium Biskupów (OŚBPD 25). Podczas święceń prezbiteratu ręce na kandydatów kładą wszyscy obecni biskupi i prezbiterzy, aby w ten sposób wyrazić ich przyjęcie do prezbiterium (OŚBPD 112). Natomiast przy święceniach diakonatu ręce nakłada sam tylko biskup, ponieważ diakonów, którzy w realizacji zadań swojej „diakonii będą pozostawać w ścisłej relacji z biskupem, święci się «nie dla kapłaństwa, lecz dla posługi»" (KKK 1569; KK 29; OŚBPD 179). Nałożenie rąk w odnowionej po Vaticanum II liturgii święceń ma zatem, w każdym z trzech stopni, różne znaczenie, które jest zawarte i wyrażone w sposób szczególny w epiklezie, będącej rdzeniem każdej modlitwy święceń. Występując w strukturze liturgii święceń jako widzialny znak niedostrzegalnej dla oka ludzkiego rzeczywistości nadprzyrodzonej, objawia ono stopniowe przenikanie człowieka Duchem Ojca i Syna $w$ trakcie przyjmowania poszczególnych święceń, wyciskając na duszy wyświęcanego pieczęcie, które są jakby rysami zwiększającego się stopniowo podobieństwa do Chrystusa.

Skoro posoborowa reforma liturgiczna, w celu nadania obrzędom święceń większej czytelności i przejrzystości, wyakcentowała na nowo obrzęd nałożenia rąk i modlitwę święceń, przywracając im pierwotne znaczenie, to warto byłoby się zastanowić nad genezą i sensem teologicznym tego ważnego gestu, jak i nad jego lokalizacją w strukturze celebracji święceń na przestrzeni wieków. Stąd też podjęcie refleksji nad znaczeniem gestu nałożenia rąk w rozwijającej się i ulegającej różnorodnym zmianom liturgii święceń w pierwszym tysiącleciu jest próbą udzielania odpowiedzi na pytania, jak doszło do „zepchnięcia” istotnych czynności nałożenia rąk i następującej tuż po nim modlitwy święceń na dalszy plan i co zajęło ich miejsce, że po wiekach należało na nowo podjąć wysiłek odsłonięcia czy też wydobycia z powrotem na sam wierzch tego, co pierwotnie było pulsującym sercem w dynamice całej celebracji. Ze względu na rozległość tematu opracowanie podzielono na dwie części. W pierwszej części zostaną ukazane biblijno-patrystyczne podstawy nałożenia rąk oraz znaczenie tego gestu

\footnotetext{
${ }^{2}$ Por. K. KoneCKI, Nałożenie rąk $w$ odnowionych obrzędach święceń, w: Ante Deum stantes, red. S. Koperek, R. Tyrała, Kraków: Wydawnictwo UNUM 2002, s. 297.
} 
w strukturze celebracji święceń w starożytności chrześcijańskiej w świetle analizy dwóch kluczowych dokumentów, jakimi są Tradycja apostolska i Statuta Ecclesiae Antiqua.

\section{NAŁOŻENIE RĄK W NOWYM TESTAMENCIE I W LITERATURZE PATRYSTYCZNEJ}

W Nowym Testamencie nałożenie rąk służy przekazywaniu duchowej władzy i uprawnień do wypełniania określonych posług i misji w Kościele, jak również jest transmisją duchowych darów i samego Ducha w kontekście

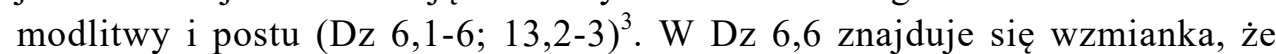
przekazanie urzędu Siedmiu odbyło się w dwóch etapach: przedstawienie Apostołom i nałożenie na nich rąk. Członkowie gminy chrześcijańskiej po wyborze pierwszych diakonów ,przedstawili ich Apostołom, którzy, modląc się, położyli na nich ręce". Gest nałożenia rąk na kandydatów do posługi jest w tym przypadku swego rodzaju gestem ordynacji, święceń, które według Tradycji Kościoła były pierwszymi święceniami diakonatu ${ }^{4}$. Ojciec Józef Rosłon w obrzędzie z Dz 6,1-6 dostrzega główny argument na twierdzenie, że owych siedmiu otrzymało święcenia diakonatu i opowiada się za teorią, w świetle której Apostołowie przyjęli ten gest z judaizmu, dodając równocześnie, że był on również znany w świecie hellenistycznym. W swojej egzegezie tego tekstu blibijnego wspomniany autor odwołuje się jeszcze do dwóch innych miejsc w Dziejach apostolskich, w których zachodzi analogiczna sytuacja, jak przy ustanawianiu siedmiu „diakonów”. Najpierw przywołuje zatem zdarzenie z Dz 13,1-3, gdzie dwom mężom - Barnabie i Szawłowi nałożono ręce $\mathrm{w}$ celu wyposażenia ich we wszystkie uprawnienia niezbędne do podjęcie ewangelizacji wśród pogan i do zakładania nowych gmin chrześcijańskich. Następnie odwołuje się do tekstu z Dz 14, 23, w którym jest mowa o tym, że ci sami mężowie podczas swojej pierwszej podróży misyjnej wśród modlitw i postów ustanawiali prezbiterów i polecali ich Panu. W tym tekście po raz pierwszy mamy wyraźnie poświadczony przebieg aktu nadania urzędu kościelnego tzw. prezbiterom. J. Rosłon na podstawie analizy przytoczonych wyżej tekstów dochodzi do wniosku, że

\footnotetext{
${ }^{3}$ Por. S. HARĘZGA, Nakładanie rąk, w: Encyklopedia katolicka, t. 13, Lublin: Towarzystwo Naukowe KUL 2009, kol. 678.

${ }^{4}$ Por. S. STASiaK, Komentarz do Dziejów apostolskich, Listu do Rzymian, 1-2 Listu do Koryntian i Listu do Galatów. Komentarz teologiczno-pastoralny do Biblii Tysiąclecia, t. 2. Poznań: Wydawnictwo Pallottinum 2014, s. 65.
} 
w Nowym Testamencie „nie zawsze nakładanie rąk, nawet kiedy towarzyszy im modlitwa i post, można rozumieć w sensie nadania urzędu kościelnego czy aktu święceń w dzisiejszym znaczeniu tego słowa". Niemniej jednak należy przyznać rację Giampaolo Cavalliemu, który zauważa, że obydwa teksty biblijne (Dz 6, 6 i Dz 13,1-3) proponują identyczny model, w którym nałożenie rąk jest zlokalizowane w kontekście modlitwy. Sens tego gestu wiąże się w tym przypadku $\mathrm{z}$ transmisją daru pentekostalnego ${ }^{5}$.

Świadectwo Dziejów apostolskich w tej materii potwierdzają listy pasterskie. W 1 Tm przypomina się odbiorcy: „nie zaniedbuj w sobie charyzmatu, który został ci dany [...] przez nałożenie rąk kolegium prezbiterów" (1 Tm 4, 14). Nałożenie rąk oznacza tutaj przekazanie charyzmatu władzy ${ }^{6}$. W analogiczny sposób także w 2 Tm 6, 6 następuje uświadomienie Tymoteuszowi, ale także wspólnocie Kościoła, której on przewodniczy, doniosłego faktu nałożenia rąk, którego dokonał Paweł: „przypominam ci, abyś rozpalił na nowo charyzmat Boży, który jest w tobie od nałożenia moich rąk". Pomiędzy obydwoma tekstami istnieje subtelna, jakkolwiek istotna różnica. W $1 \mathrm{Tm}$ wspomina się o nałożeniu rąk przez Pawła i prezbiterium, podczas gdy w 2 Tm zostaje wspomniane jedynie nałożenie rąk Pawła. Joachim Gnilka zauważa, że przyczyny tej rozbieżności należy upatrywać w odmiennym charakterze obu listów do Tymoteusza. Pierwszy z nich miałby zawierać wersję oficjalną, drugi zaś - mający charakter listu pożegnalnego - wersję osobistą ${ }^{7}$. Listy pasterskie są dowodem na istnienie ścisłej relacji między nałożeniem rąk a przekazywaniem daru potrzebnego do wykonywania specjalnego „urzędu”. W analizowanych fragmentach powiązanie między nałożeniem a darem wydaje się czymś oczywistym. Natomiast brakuje tutaj wyraźnej wzmianki o modlitwie i odniesienia do osoby Ducha Świętego. Reasumując powyższe rozważania nad znaczeniem gestu nałożenia rąk przy przekazywaniu urzędu w pierwotnym Kościele na podstawie obrazu, jaki wyłania się z analizy listów pasterskich, należy przyznać rację J. Gnilce, który nałożenie rąk uznaje za czynność centralną obrzędu święceń. Nakładając ręce na kandydata, udzielano mu charyzmatu właściwego danemu urzędowi. To, że raz tego gestu dokonuje Paweł, a kiedy indziej kolegium prezbiterów, nie przekreśla sukcesji nakładania rąk. Istotne

\footnotetext{
${ }^{5}$ G. Cavalli, L'imposizione delle mani nella tradizione della Chiesa latina. Un rito che qualifica il Sacramento, (Studia Antoniana 38), Roma: Edizioni Antonianum 1999, s. 46.

${ }^{6}$ Por. J.J. KobyŁka, H. LangKammer, M. MikolajczaK, Komentarz do 1-2 Listu do Tymoteusza, Listu do Tytusa, Listu do Filemona i Listu do Hebrajczyków. Komentarz teologicznopastoralny do Biblii Tysiaclecia, t. 4, Poznań: Wydawnictwo Pallottinum 2015, s. 58.

${ }^{7}$ Por. J. GNILKA, Teologia Nowego Testamentu, przeł. W. Szymona, Kraków: Wydawnictwo M 2002, s. 466.
} 
jest w tym przypadku to, że gest ten ma pochodzenie apostolskie. Zarówno

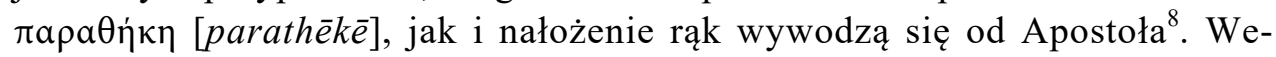
dług opinii wspomnianego biblisty obrzęd nałożenia rąk, o którym tutaj mowa, nawiązuje do żydowsko-rabinackiego nakładania rąk, ale ze względu na udzielany tu charyzmat staje się on odrębnym i niezależnym rytem ${ }^{9}$.

Odmienne stanowisko prezentuje John Kevin Coyle. Uważa on, że rzeczywistość wydaje się bardziej złożona od tego, co zakładają badacze, którzy wywodzą gest nałożenia rąk z judaizmu i utożsamiają go z udzieleniem Ducha czy też daru Ducha bądź przekazaniem władzy lub autorytetu. Według J.K. Coyle'a nie jest możliwe zajmowanie się jakimikolwiek aluzjami biblijnymi do nałożenia rąk bez uwzględnienia rozumienia posługi ministerialnej w Piśmie Świętym. Stary Testament - zdaniem wspomnianego autora - rzuca niewiele światła na Nowy i być może Nowy Testament niewiele w tej materii zaczerpną̧ ze Starego Testamentu. Dominującej w późniejszym czasie koncepcji, upatrującej w lewickim kapłaństwie prekursora chrześcijańskiej hierarchii i uznającej gest nałożenia rąk za gwarancję nieprzerwanej sukcesji biskupiej, sięgającej wstecz nie tylko do Apostołów, ale do Mojżesza, J.K. Coyle zarzuca pominięcie informacji zawartej w Lb 27,18, gdzie jest mowa o tym, że Duch został udzielony Jozuemu, zanim Mojżesz nałożył na niego ręce. Koncepcja powyższa opiera się na Pwt 34,9. Fragment ten wskazuje na fakt napełnienia Jozuego, syna Nuna duchem mądrości, którego przyczyną sprawczą staje się nałożenie rąk przez Mojżesza. J.K. Coyle jako argument przemawiający za podaniem w wątpliwość tej koncepcji wysuwa fakt zignorowania przez jej zwolenników możliwości, że zdanie przyczynowe w Pwt 34,9 może pasować zarówno do tego, co po nim następuje, jak i do tego, co je poprzedza. Wtedy da się ono pogodzić z Lb 27,18 i w obydwu przypadkach jako skutek gestu Mojżesza ukazuje nie obecność Ducha, ale przyjęcie Jozuego przez lud. W swojej konkluzji J.K. Coyle podkreśla, że wszelkie argumenty na rzecz starotestamentalnego źródła stosowania w Nowym Testamencie nakładania rąk powinny wziąć pod uwagę rolę wspólnoty w przyjęciu osoby czy też osób wybranych przez Boga, aby jej posługiwać ${ }^{10}$.

Jakkolwiek teza J.K. Coyle'a jest interesująca sama w sobie, pozostaje ona jednak odosobniona. Rację należy raczej przyznać G. Cavalliemu, który

\footnotetext{
${ }^{8}$ Por. tamże, s. 469.

${ }^{9}$ Por. tamże, s. 467.

${ }^{10}$ Por. J. K. Coyle, The Laying on of Hands as Conferral of the Spirit: Some Problems and a Possible Solution, w: Studia Patristica, vol. XVIII, 2: Papers of the 1983 Oxford Patristics Conference "Critica, Classica, Ascetica, Liturgica", red. E.A. Livingstone, Leuven: Peeters Publishers 1989, s. 340-341.
} 
stoi na stanowisku, że w obydwóch analizowanych fragmentach biblijnych, Pwt 34, 9 i Lb 27,18-23, gest obrzędowy i dar - obecność Ducha pozostają $\mathrm{w}$ ścisłej z sobą relacji. W tej optyce nałożenie rąk jawi się jako gest desygnacji Jozuego na następcę Mojżesza, a jego skutkiem będzie udział Jozuego w tym autorytecie, jakim się cieszył Mojżesz wśród Izraelitów. Chodzi tutaj zatem zarówno o wprowadzenie na urząd, jak i o akceptację desygnowanej osoby przez lud. Zdaniem G. Cavalliego obydwa fragmenty biblijne wywierają wielki wpływ na późniejszą tradycję. Stąd też instalację Jozuego przez Mojżesza można uznać za archetyp obrzędów święceń wspólnoty chrześcijańskiej ${ }^{11}$.

Listy do Tymoteusza (1 Tm 4,14; 5,22; 2 Tm 1,6) i List do Hebrajczyków (Hbr 6,2) wydają się sugerować, że w niektórych wspólnotach chrześcijańskich już przed końcem I wieku nałożenie rąk byłoby obecne pośród rytów inicjacji i ustanawiania na urząd. Dokumenty jednak bliższe pismom nowotestamentalnym nie odnoszą się do nałożenia rąk w tych momentach życia eklezjalnego. W celu znalezienia tekstów, które mogłyby być dla nas przedmiotem zainteresowania w tej materii, potrzeba poczekać aż do końca II wieku. Pisma Ojców apostolskich (1. połowa II wieku), chociaż dokumentują proces wyodrębniania się trójstopniowej hierarchii kościelnej, czego dość szczegółowy opis znajdziemy w listach Ignacego Antiocheńskiego czy w Pierwszym Liście Klemensa Rzymskiego, nie wspominają o nałożeniu rąk.

\section{NAŁOŻENIE RĄK W TRADYCJI APOSTOLSKIEJ}

Tradycja apostolska z początku III wieku stanowi szczególnie ważne świadectwo liturgii święceń, ponieważ zawiera właściwy obrzęd, który porządkuje i reguluje kwestie związane $\mathrm{z}$ przekazaniem urzędu w obrębie wspólnoty eklezjalnej w ramach celebracji eucharystycznej. Niestety, wątpliwości co do pochodzenia i proweniencji tego kanonu kościelnego - jak słusznie zauważa Paul F. Bradshaw - sprawiają, że Tradycja apostolska jest „świadectwem bardzo niepewnym”, a zawarte w niej zalecenia dotyczące święceń podlegały różnorodnym modyfikacjom ${ }^{12}$.

Porządek hierarchiczny Kościoła, odbijający się jak w zwierciadle w rytach i formularzach euchologijnych Tradycji apostolskiej, znajdzie usankcjo-

\footnotetext{
${ }^{11}$ G. CAVAlli, L'imposizione delle mani nella tradizione della Chiesa latina, s. 35-36.

${ }^{12}$ Por. P.F. Bradshaw, W poszukiwaniu początków kultu chrześcijańskiego. Źródta i metody wczesnej liturgii, przeł. P. Kaznowski i M. Koza, Kraków: Fundacja Dominikański Ośrodek Liturgiczny 2016, s. 364.
} 
nowanie siedemnaście wieków później w Konstytucji apostolskiej Sacramentum Ordinis papieża Piusa XII (1947) oraz w Konstytucji Lumen gentium Soboru Watykańskiego II. W ujęciu historycznym znaczenie Tradycji apostolskiej potęguje fakt, że jest ona źródłem, od którego zależą wszystkie obrzędy święceń Kościoła. Gestu nałożenia rąk w schemacie obrzędowym Tradycji apostolskiej używa się dla powierzenia urzędu biskupa, prezbitera i diakona.

\section{A. NAŁOŻENIE RĄK W ŚWIĘCENIACH BISKUPICH}

Obrzęd święceń biskupich w Tradycji apostolskiej można określić mianem rytu-paradygmatu dla święceń prezbitera i diakona ${ }^{13}$. Mauro Paternoster zauważa, że schemat liturgiczny dla powierzenia urzędu biskupiego przewiduje pewne następstwo gestów i momentów obrzędowych w ścisłej z sobą relacji ${ }^{14}$. W tej perspektywie szczególnie istotne wydaje się uwzględnienie całej struktury obrzędu, gdyż dopiero na tym tle można rozpoznać prawdziwy walor liturgiczny gestu nałożenia rąk, który odgrywa główną rolę w dynamice celebracji święceń biskupich. Wybór biskupa przez całą wspólnotę, ogłoszenie jego imienia i wyrażenie powszechnej zgody przez lud, sama niedziela jako czas udzielania święceń i obecność całego Ludu Bożego, prezbiterów i biskupów, czyli to wszystko, co w strukturze celebracji stanowi etap przygotowawczy do właściwego obrzędu święceń, uwypukla eklezjologiczną wartość gestu nałożenia rąk. Z analizy tekstu Tradycji apostolskiej wynika, że mamy tu do czynienia z podwójnym nałożeniem rąk, któremu towarzyszy modlitwa: „Biskupi włożą na kandydata ręce, natomiast kolegium prezbiterów będzie przy tym jedynie asystować biernie. Wszyscy zebrani zachowają milczenie, modląc się w głębi serca, by na wyświęconego zstąpił Duch Święty, jeden zaś z biskupów, specjalnie o to uproszony, odmówi podczas wkładania rąk następującą modlitwę"15. Pierwsze nałożenie rąk jest dokonywane przez wszystkich członków ordo episcoporum, którzy uczestniczą w święceniach, podczas gdy wszyscy obecni modlą się w ciszy.

\footnotetext{
${ }^{13}$ Por. A. CAtTella. L'evoluzione dei modelli rituali della liturgia di ordinazione, w: Le liturgie di ordinazione. Atti della XXIV Settimana di Studio dell'Associazione Professori di Liturgia, Loreto, 27 agosto-1 settembre 1995, (Bibliotheca „Ephemerides Liturgiae”. „Subsidia” 86), Roma: C.L.V.-Edizioni liturgiche 1996, s. 28-29.

${ }^{14}$ Por. M. PATERnOSTER, L'imposizione delle mani nella chiesa primitiva. Rassegna delle testimonianze bibliche, patristiche e liturgiche fino al secolo quinto, (Bibliotheca „Ephemerides Liturgicae” „Subsidia” 12), Roma: C.L.V.-Edizioni liturgiche 1983, s. 4.

${ }^{15}$ Tradycja apostolska, I, 1, w: M. MichALSKI, Antologia literatury patrystycznej, t. 1, z. 2, Warszawa: Instytut Wydawniczy PAX 1969, s. 85.
} 
Z kolei drugie staje się prerogatywą jednego biskupa - tego, który w imieniu i na prośbę pozostałych wypowiada słowa modlitwy święceń.

Liturgiści przedstawiają różne interpretacje podwójnego nałożenia rąk w opisie święceń biskupich według Tradycji apostolskiej. Z formalnego punktu widzenia - jak zauważa G. Cavalli - w święceniach biskupich można wyodrębnić dwa nałożenia rąk, które lokalizują się w ramach jednego działania obrzędowego, rozwijającego się w dwóch momentach celebratywnych. Centrum scalającym akcję liturgiczną jest wymiar epikletyczny ${ }^{16}$. M. Paternoster wyjaśnia znaczenie tego podwójnego nałożenia rąk. W pierwszym nałożeniu rąk, dokonywanym przez wszystkich biskupów, manifestuje się jego zdaniem - zgoda członków ordo episcoporum na wybór dokonany przez lud i stanowi ono moment epikletyczny całej celebracji święceń biskupich. Natomiast drugie nałożenie rąk rozpatruje on w kategorii prawdziwego gestu liturgicznego w celu przekazania biskupiego charyzmatu, który modlitwa święceń we właściwym czasie rozwinie i scharakteryzuje w relacji do wspólnoty eklezjalnej. Reasumując swoje rozważania, wspomniany autor konkluduje, że gest nałożenia rąk wyraża, za pośrednictwem kontaktu fizycznego, transmisję i przekazanie wyraźnego charyzmatu ministerialnego, który uzdalnia nowo wyświęconego do rozwinięcia określonych funkcji ministerialnych w obrębie ludu Bożego ${ }^{17}$. W innym swoim opracowaniu ten sam autor stwierdza, że podwójne nałożenie rąk w opisie święceń biskupich zawartym w Tradycji apostolskiej to skutek nałożenia się na siebie dwóch różnych schematów obrzędowych ${ }^{18}$.

$\mathrm{Z}$ kolei Antonio Santantoni dostrzega w dwóch nałożeniach rąk, następujących po sobie, jeden gest, który w tym samym czasie jest błaganiem o dar Ducha Świętego i Jego przekazywaniem ${ }^{19}$. W analogiczny sposób wypowiada się również Bruno Kleinheyer. Liturgista ten wychodzi z założenia, że nałożenie rąk przez biskupa, który $\mathrm{w}$ imieniu pozostałych wypowiada słowa modlitwy święceń, nie może być uznane za odrębny bądź dodatkowy gest liturgiczny, ale chodzi w tym przypadku raczej o kontynuację znaku centralnego, w którym wcześniej uczestniczyli wszyscy członkowie ordo episcoporum ${ }^{20}$.

\footnotetext{
${ }^{16}$ Por. G. CAVAlli, L'imposizione delle mani nella tradizione della Chiesa latina, s. 60.

${ }^{17}$ Por. M. PATERNOSTER, L'imposizione delle mani nella chiesa primitiva, s. 6-7.

${ }^{18}$ Por. TENŻE, Il ministero nella Traditio apostolica di Ippolito e nelle costituzioni ecclesiastiche della chiesa antica, w: Teologia del Sacerdozio, t. 11: El ministero en los primeros siglos, Burgos: Aldecoa 1979, s. 99-101.

${ }^{19}$ Por. A. SANTANTONI, L'ordinazione episcopale. Storia e teologia dei riti dell'ordinazione nelle antiche liturgie dell'Occidente, Roma: Editrice Anselmiana 1976, s. 33.

${ }^{20}$ Por. B. KleINHeyer, Ordinazioni e ministeri, w: La liturgia della Chiesa. Manuale di scienza liturgica, vol. 9: Celebrazioni sacramentali - III: Ordine, Matrimonio, Vita religiosa,
} 
Istotne w opisie święceń biskupich zawartym w Tradycji apostolskiej jest także i to, że tylko biskupi, a nie całe prezbiterium, biorą udział w nałożeniu rąk. Oznacza to - jak zauważa Bruno Kleinheyer - że w święceniach biskupich kolegialność ordo episcoporum jest ważniejsza od kolegialności, która wiąże poszczególnego biskupa $\mathrm{z}$ jego prezbiterium. Poza tym $\mathrm{w}$ geście nałożenia rąk, który zajmuje centralne miejsce w dynamice całej celebracji, obecni biskupi manifestują swoją odpowiedzialność za wszystkie Kościoły lokalne. Odpowiedzialność ta rozciąga się zatem poza granice ich własnego Kościoła ${ }^{21}$.

Ciekawą opinię na temat gestu nałożenia rąk i udziału członków Kolegium Biskupów w święceniach biskupich według przekazu Tradycji apostolskiej przedstawia Paul F. Bradshaw ${ }^{22}$. Wychodzi on z założenia, że różne wersje językowe Tradycji apostolskiej różnią się zasadniczo co do wspominania czynnej obecności innych biskupów w liturgicznym akcie transmisji daru pentekostalnego. Autor ten przyznaje rację Edwardowi Ratcliffowi, który zestawiając różne wersje Tradycji apostolskiej, wysuwa tezę o czynnej roli prezbiterów w święceniach biskupich w pierwotnej formie tego dokumentu $^{23}$. Zdaniem P.F. Bradshawa pierwsza część wskazówek w Tradycji apostolskiej 2.1-4 brzmiała na samym początku najprawdopodobniej w następujący sposób: „Niech zostanie wyświęcony na biskupa ten, który został wybrany przez cały lud, a kiedy został nominowany i przyjęty, niech cały lud zbierze się razem z prezbiterium w Dzień Pański. Gdy wszyscy wyrażą przyzwolenie, niech prezbiterium nałoży na niego dłonie, a wszyscy niech zachowają milczenie, modląc się w sercu o zstąpienie Ducha" ${ }^{24}$. Wspomniany autor dochodzi do wniosku, że obrzęd święceń biskupich zawarty w tekście Tradycji apostolskiej zachowanym do naszych czasów nie jest najstarszą formą, ale został uformowany przez złożenie dwóch pierwotnie odrębnych elementów: przytoczonego powyżej fragmentu oraz tego, co po nim następuje w Tradycji apostolskiej (2.5). Według P.F. Bradshawa w pierwszym z dwóch obrzędów pierwotnie prezbiterzy nakładali razem ręce na kandydata i wszyscy modlili się w milczeniu o zstąpienie Ducha Świętego. Natomiast w drugim, później-

Esequie, Benedizioni, Esorcismo, red. B. Kleinheyer, E. von Servus, R. Kaczyński, Torino: Elledici 1994 s. 48.

${ }^{21}$ Por. tamże.

${ }^{22}$ Por. P.F. BRadshaw, Rites of Ordination. Their History and Theology, Collegeville: Order of Saint Benedict 2014, s. 59-61.

${ }^{23}$ Por. E.C. RATCLIFF, Apostolic Tradition: Questions concerning the Appointment of the Bishop, ,Studia Patristica” 8 (1966), s. 266-270.

${ }^{24}$ Por. P.F. BRADShaw, Rites of Ordination, s. 60: „Let him be ordained bishop who has been chosen by all the people, and when he has been named and accepted, let all the people assemble together with the presbytery on the Lord's day. When all give consent, let the presbytery lay hands on him, and let all keep silence, praying ih the heart for the descent of the Spirit". 
szym chronologicznie obrzędzie to jeden z biskupów (a może jeden z prezbiterów?) pełnił pierwszoplanową funkcję, ponieważ w imieniu pozostałych sam nakładał ręce na elekta i wypowiadał modlitwę święceń. W ten sposób mamy do czynienia $\mathrm{z}$ dwoma całkiem odmiennymi sposobami udzielania święceń. Wcześniejszy z nich zniknął właściwie bez śladu - jak zauważa P.F. Bradshaw - w późniejszych tradycjach, gdzie wspólna modlitwa następuje tylko jako wstęp do właściwej modlitwy święceń, a wspólne nałożenie rąk pojawia się tylko w tekstach wywodzących się z samej Tradycji apostolskiej ${ }^{25}$. Według P.F. Bradshawa rozmaite informacje wskazujące na czynny udział innych członków ordo episcoporum w święceniach biskupich mogły być wstawione później przez redaktorów poszczególnych wersji Tradycji apostolskiej po to, aby tekst pozostawał w harmonii z tym, co w ich czasie stało się już standardową ówczesną praktyką ${ }^{26}$.

\section{B. NAŁOŻENIE RĄK W ŚWIĘCENIACH PREZBITERATU I DIAKONATU}

W zestawieniu z wcześniejszym pełnym teologicznych treści opisem święceń biskupich opis święceń prezbitera zawarty w Tradycji apostolskiej prezentuje się wyjątkowo skromnie. Brak w nim wzmianki zarówno o wyborze kandydata, jak i o istnieniu jakiegokolwiek gestu, który poprzedzałby bądź następował po nałożeniu rąk, jawiącym się jako fundamentalny dla przekazania sakramentalnej łaski. Biskup kładzie rękę na głowie diakona wyświęcanego na prezbitera, a gdy dotkną go również inni prezbiterzy, odmawia nad nim modlitwę święceń. Chociaż w obydwu przypadkach mamy do czynienia $\mathrm{w}$ wymiarze zewnętrznym $\mathrm{z}$ tym samym gestem liturgicznym, to jednak jego teologiczne znaczenie diametralnie różni się w zależności od tego, kto nakłada ręce - biskup czy prezbiter. W Tradycji apostolskiej znajdujemy następujące uzasadnienie teologiczne impositio manuum ordo presbyterorum $\mathrm{w}$ schemacie obrzędowym święceń prezbiteratu: „na prezbitera wkładają ręce również inni prezbiterzy, ponieważ ma on otrzymać wspólnego im wszystkim Ducha i stać się równy im pod względem rangi. Jednakże prezbiter może tylko otrzymać władzę, nie zaś udzielać jej drugim; dlatego nie wyświęca on członków kleru, lecz tylko zaznacza swój współudział przy udzielaniu przez biskupa święceń prezbiteratu" ${ }^{27}$. Według opinii Mario Righettiego nałożenie rąk przez członków prezbiterium nie ma waloru sakramentalnego, ponieważ prezbiterzy nie są szafarzami święceń. Gest ten

\footnotetext{
${ }^{25}$ Por. tamże, s. 61

${ }^{26}$ Por. tamże, s. 60.

${ }^{27}$ Tradycja apostolska, I, 3, w: Antologia literatury patrystycznej, s. 88.
} 
jest raczej wyrażaniem solidarności z działaniem biskupa ${ }^{28}$. W ten sposób Hipolit bardzo wyraźnie uwypukla fakt, że tylko biskup może udzielać święceń, gdyż prezbiter nie ma takiej władzy. Nałożenie rąk w przypadku prezbiterów jest zatem ,znakiem uczestnictwa w tej samej łasce i $\mathrm{w}$ tej samej posłudze" ${ }^{, 29}$. Z tego punktu widzenia gest ten wykonywany przez członków ordo presbyterorum ma wymiar horyzontalny i jest ekspresją więzi komunii istniejących $\mathrm{w}$ obrębie prezbiterium ${ }^{30}$. M. Paternoster, który genezy tego gestu doszukuje się $\mathrm{w}$ tradycji rabinistycznej, proponuje, aby łacińską frazę contingentibus etiam presbyteris interpretować jako wyrażenie zgody i udział prezbiterów w działaniu obrzędowym biskupa, a tym samym widzi on $\mathrm{w}$ tym geście manifestację kolegialności właściwej dla prezbiterium $^{31}$. Obydwa nałożenia rąk w święceniach prezbiteratu nie mają zatem tej samej rangi $z$ punktu widzenia ontologii sakramentalnej, jak to miało miejsce w przypadku święceń biskupich, ponieważ prezbiter może tylko otrzymać, a nie dawać; może, by tak powiedzieć, święcenia uwierzytelnić (consignare), ale jedynie biskup jest szafarzem święceńn ${ }^{32}$.

W celu ustalenia sensu teologicznego gestu nałożenia rąk w przypadku święceń prezbiteratu należy także wziąć pod uwagę kwestię terminologii. W wersji sahidzkiej Tradycji apostolskiej po łacińskim słowie ordinatur

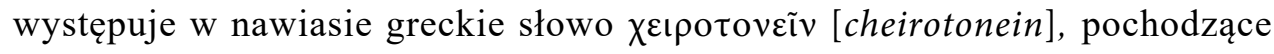
$\mathrm{z}$ tekstu oryginalnego tego dokumentu. Tradycja apostolska posługuje się

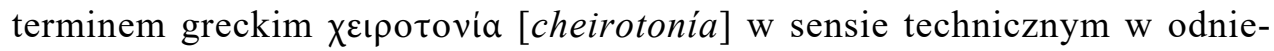
sieniu do święceń biskupich, prezbiteratu i diakonatu i rozumie pod tym pojęciem gest oznaczający władzę ordynacji, przekazania łaski. Obok tego

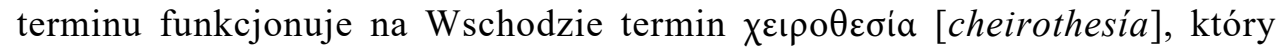
nie identyfikuje się z sakramentalnym święceniem, ale oznacza zwykłe błogosławieństwo. W tej optyce nałożenie rąk przez prezbiterów podczas celebracji święceń należałoby określić właśnie mianem $\chi \varepsilon ı \rho o \theta \varepsilon \sigma i a$ [cheirothesía], gdyż prezbiter w ten sposób nie przekazuje łaski sakramentalnej, ale akceptuje włączenie nowego członka w kolegium prezbiterów.

\footnotetext{
${ }^{28}$ Por. M. RighetTI, Manuale di storia liturgica, t. 4: I sacramenti - I sacramentali, II edizione anastatica, Roma: Ancora 2005, s. 405.

${ }^{29}$ D. KwiatKowsKi, Obrzędy święceń prezbiteratu do X wieku, w: Studia liturgiczne, t. 7: Prezbiterzy w Kościele do Soboru Trydenckiego. Liturgia święceń, teologia, ministerium, red. Cz. Krakowiak, W. Pałęcki, Lublin: Towarzystwo Naukowe KUL 2011, s. 23.

${ }^{30}$ Por. G. FraUsini, Il sacramento dell'ordine. Dacci oggi il nostro pane degli apostoli, (Gestis verbisque), Assisi: Cittadella 2017, s. 174.

${ }^{31}$ Por. M. PATERnOSTER, L'imposizione delle mani nella chiesa primitiva, s. 9.

32 Por. A. Santantoni, S. PArenti, Gli ordini sacri e i ministeri, w: Scientia liturgica. Manuale di liturgia, t. 4: Sacramenti e sacramentali, Casale Monferrato: Piemme 1998, s. 217.
} 
Jeśli chodzi o święcenia diakonatu, Tradycja apostolska nie tylko podaje prosty i skromny w swojej strukturze schemat celebracji, ale także wyjaśnia problematykę teologiczną związaną z diakonatem, zwłaszcza w obrębie relacji zachodzących w trójmianie: biskup - prezbiter - diakon. Przy święceniach diakonatu tylko biskup nakłada ręce na ordynowanego. W Tradycji apostolskiej uwypukla się ścisłą zależność urzędu diakona od urzędu biskupa. Jedynie biskup w tym przypadku nakłada ręce, ponieważ „diakona wyświęca się nie do kapłaństwa, lecz do posługiwania biskupowi, by wykonywał jedynie jego polecenia"33. Według Tradycji apostolskiej funkcję ministerialną diakona charakteryzuje się $\mathrm{w}$ perspektywie działalności biskupa. B. Kleinheyer stoi na stanowisku, że wziąwszy pod uwagę to wszystko, co było wcześniej powiedziane w Tradycji apostolskiej o nałożeniu rąk $\mathrm{w}$ święceniach prezbiteratu, mamy tutaj do czynienia $\mathrm{z}$ odbiciem starożytnego modelu organizacji kościelnej, w której dominującą rolę w kierowaniu wspólnotą odgrywali biskupi i diakoni ${ }^{34}$. Pod tym względem dostrzega się różnicę chociażby z tekstem Statuta Ecclesiae Antiqua, który chociaż zasadniczo pozostaje wierny Tradycji apostolskiej, to jednak w tej materii zawiera odmienną opinię, gdyż potwierdza, że diakon posługuje zarówno biskupowi, jak i prezbiterowi ${ }^{35}$.

\section{NAŁOŻENIE RĄK W STATUTA ECCLESIAE ANTIQUA}

Kolejnym po Tradycji apostolskiej istotnym dokumentem zawierającym wskazania odnośnie co do nałożenia rąk są Statuta Ecclesiae Antiqua - zbiór kanonów południowej Galii, przypisywany Genadiuszowi z Marsylii, skomponowany przy końcu $\mathrm{V}$ wieku, który wywarł ważny wpływ na życie liturgiczne pozostałych regionów. Statuta Ecclesiae Antiqua wspominają o geście nałożenia rąk podczas okresu pokuty i katechumenatu, jak również przy pojednaniu. Najbardziej jednak interesujące nas informacje znajdują się w końcowej części dokumentu. W tej sekcji kompilator, $\mathrm{w}$ harmonii z tradycją rzymską, zarezerwował impositio manuum dla święceń biskupa, prezbitera i diakona. Natomiast w przypadku subdiakonatu nałożenie rąk jest już wyraźnie wykluczone.

\footnotetext{
${ }^{33}$ Por. Tradycja apostolska, I, 3, w: Antologia literatury patrystycznej, s. 88.

${ }^{34}$ Por. B. KleINHeYer, Ordinazioni e ministeri, s. 50.

${ }^{35}$ Por. M. PAternoster, L'imposizione delle mani nella chiesa primitiva, s. 11-12.
} 


\section{A. NAŁOŻENIE RĄK W ŚWIĘCENIACH BISKUPICH}

W schemacie obrzędowym święceń biskupich w Statuta Ecclesiae Antiqua brakuje wyraźnego i jasnego odniesienia do nałożenia rąk przez głównego szafarza święceń, czyli tego, który wypowiada słowa modlitwy święceń: „Et uno super eum fundente benedictionem, reliqui omnes Episcopi, qui adsunt, manibus suis caput eius tangant" ${ }^{36}$. Natomiast tekst wystarczająco jasno zaświadcza o nałożeniu rąk o charakterze kolektywnym - dokonują go pozostali obecni biskupi. Jak zauważa M. Paternoster, według opinii większości badaczy analizowany obrzęd przewiduje jednak także nałożenie rąk przez tego jedynego biskupa wygłaszającego modlitwę. Na ten fakt wydaje się wskazywać wyrażenie: „et uno super eum fundente benedictionem”37. Łaciński termin benedictio, który występuje także przy święceniach prezbitera i diakona, wskazywałby w tym przypadku na modlitwę, która towarzyszy nałożeniu rąk, pozostając $\mathrm{w}$ ścisłym związku celebratywnym z samym gestem nałożenia rąk. Logiczną konsekwencją tego byłoby rozwinięcie zakresu pojęcia benedictio. $\mathrm{W}$ tej optyce mianem benedictio można było określić zarówno samą formułę modlitwy, jak i nałożenie rąk towarzyszące tejże modlitwie. Jednakże „Manuskrypt LXI" z Werony - jak zauważa M. Paternoster - wydaje się anulować całą tę terminologiczną problematykę, ponieważ podaje odmienną wersję tego tekstu: „Episcopus cum ordinatur, duo Episcopi ponant Evangeliam super caput, tertius benedicat et reliqui manus imponant”. Według tego tekstu perspektywa obrzędowa jest bardziej uproszczona, gdyż mamy tu do czynienia tylko $\mathrm{z}$ jednym nałożeniem rąk - tym o charakterze kolektywnym. Tego gestu dokonują obecni biskupi, podczas gdy dwóch biskupów trzyma Księgę Ewangelii nad głową kandydata do episkopatu, trzeci zaś biskup wypowiada słowa modlitwy, która towarzyszy nałożeniu rąk przez pozostałych obecnych biskupów. Ta struktura obrzędowa wydaje się mniej skomplikowana i nie wymaga takiego wsparcia terminologicznego jak poprzedni schemat ${ }^{38}$.

\section{B. NAŁOŻENIE RĄK W ŚWIĘCENIACH PREZBITERATU}

Pewien problem z interpretacją gestu nałożenia rąk pojawia się także w opisie święceń prezbitera, zawartym w analizowanym dokumencie: „Pres-

\footnotetext{
${ }^{36}$ Por. C. Munier, Les Statuta Ecclesiae Antiqua. Edition, (Etudes critiques - Bibliothèque de l'Institut de Droit Canonique de l'Université de Strasbourg 5), Paris: Presses Universitaires de France 1960, nr 90, s. 95.

${ }^{37}$ Por. M. PATERnOSTER. L'imposizione delle mani nella chiesa primitiva s. 40-41.

${ }^{38}$ Por. tamże, s. 41.
} 
byter cum ordinatur, Episcopo eum benedicente et manum super caput eius tenente, etiam omnes Presbyteri, qui praesentes sunt, manus suas iuxta manum Episcopi super caput illius teneant" ${ }^{\prime 3}$. Powyższy tekst wydaje się na pierwszy rzut oka wskazywać na podwójne nałożenie rąk. W rzeczywistości jednak nałożenie rąk jest tylko jedno, chociaż zakłada ono czynny udział w tym geście obecnych prezbiterów. Oczywiście gest prezbiterów nabiera ścisłego znaczenia teologiczno-liturgicznego tylko w powiązaniu i w ścisłej zależności od gestu biskupa, który pozostaje gestem konstytutywnym z punktu widzenia ontologii sakramentalnej dla transmisji charyzmatu związanego $\mathrm{z}$ urzędem prezbitera ${ }^{40}$.

\section{NAŁOŻENIE RĄK W ŚWIĘCENIACH DIAKONATU}

W obrzędzie święceń diakonatu, aż do momentu przywołania uzasadnienia, gest nałożenia rąk, które w tym przypadku jest wyłączną prerogatywą biskupa, Statuta Ecclesia Antiqua stanowią wierne odzwierciedlenie tekstu Tradycji apostolskiej: „Diaconus cum ordinatur, solus episcopus, qui eum benedicit, manum super caput illius ponat, quia non ad sacerdotium sed ad ministerium consecratur" ${ }^{\prime 4}$. Znacząca zmiana, mająca swoje reperkusje na płaszczyźnie teologicznej, jeśli chodzi o wizję samego diakonatu, polega na tym, że kwalifikując diakona do posługi, nie podaje się głównego odbiorcy tejże posługi, czyli osoby biskupa. Wydaje się, że ten istotny brak odniesienia do urzędu biskupa może wskazywać na istnienie w tamtym czasie sytuacji, w której najprawdopodobniej diakon nie pozostawał w relacji wyłącznej zależności od osoby biskupa w realizacji swojej posługi ${ }^{42}$.

G. Cavalli zwraca uwagę na precyzję języka, jaki został użyty w kanonach Statuta Ecclesiae Antiqua. Dokument ten wiąże gest nałożenia rąk tylko ze święceniami biskupa, prezbitera i diakona. Chociaż posługuje się określeniem święcenia także wtedy, gdy nie ma mowy o nałożeniu rąk, to jednak odniesienie do terminu benedicere pojawia się wyłącznie w przypadku trójmianu biskup - prezbiter - diakon. Zależność między tymi dwoma terminami, impositio manuum i benedicere, przewija się przez cały dokument. Statuta Ecclesiae Antiqua tylko raz posługują się pojęciem benedicere bez jakiejkolwiek wzmianki o nałożeniu rąk. Ma to miejsce w obrzędach małżeństwa przy prezentacji narzeczonych kapłanowi. Mając jednak na

\footnotetext{
${ }^{39}$ Por. C. Munier, Les Statuta Ecclesiae Antiqua, nr 91, s. 95-96.

${ }^{40}$ Por. M. PAternoster, L'imposizione delle mani nella chiesa primitiva, s. 42.

${ }^{41}$ Por. C. Munier, Les Statuta Ecclesiae Antiqua, nr 92, s. 96.

${ }^{42}$ Por. G. Cavalli, L'imposizione delle mani nella tradizione della Chiesa latina, s. 97.
} 
względzie cały kontekst liturgiczny użycia tego wyrażenia, także i w przypadku obrzędu błogosławieństwa narzeczonych wydaje się wielce prawdopodobne, że towarzyszył temu starożytny gest nałożenia rąk $k^{43}$. Do podobnych wniosków na podstawie Statuta Ecclesiae Antiqua dochodzi Cyrille Vogel. Autor ten słusznie zauważa, że w analizowanym dokumencie zostaje ustanowiona zasada, która pozostanie niezmienna w kwestii święceń na Zachodzie: nałożenie rąk występuje tylko przy święceniach biskupa, prezbitera i diakona. Nie ma natomiast żadnej wzmianki o impositio manus podczas wprowadzenia w urząd subdiakona, akolity, egzorcysty, lektora czy ostiariusza, gdyż posługiwania nie należą do liturgii święceń. Dla wszystkich tych funkcji Statuta Ecclesiae Antiqua używają słowa ordinari ${ }^{44}$.

Reasumując powyższe rozważania, można skonkludować, że w omawianym dokumencie podobnie, jak w Tradycji apostolskiej, funkcjonuje model, w którym nałożenie rąk stanowi centralny moment święceń. W schemacie obrzędowym święceń w Statuta Ecclesiae Antiqua są jednak pewne nowe elementy, których wcześniej nie było. W święceniach biskupa, obok nałożenia rąk, jest przewidziany ryt nałożenia księgi Ewangelii na głowę wyświęcanego. Księgę Ewangelii nakładają na elekta dwaj biskupi ${ }^{45}$. Nie ma zgodności w opiniach liturgistów co do pochodzenia tego rytu. Na pewno nie narodził się w Galii ${ }^{46}$. Zdaniem Bernarda Botte Statuta Ecclesiae Antiqua mogły zaczerpnąć go z dwóch alternatywnych źródeł - z Konstytucji apostolskich lub z praktyki rzymskiej ${ }^{47}$. W rozdziale ósmym Konstytucji apostolskich, powstałych około $380 \mathrm{r}$. w Antiochii, wspomina się bowiem o diakonach trzymających podczas ordynacji biskupiej nad głową ordynowanego otwartej księgi Bożej Ewangelii ${ }^{48}$.

${ }^{43}$ Por. tamże, s. 97-98; P. Galtier, Imposition des mains, w: Dictionnaire de théologie catholique, red. A. Vacant, E. Mangenot, t. 7/2, Paris: Librairie Letouzey 1923, kol. 1335.

${ }^{44}$ Por. C. Vogel, L'imposition des mains dans les rites d'ordination en Orient et en Occident, „La Maison-Dieu” 1970, nr 102, s. 67. Brak nałożenia rąk również w przypadku psalmistów, dziewic i wdów.

${ }^{45}$ Por. C. Munier, Les Statuta Ecclesiae Antiqua, nr 90: „Episcopus eum ordinatur, duo episcopi ponant et teneant euangeliorum codicem super cervice eius".

${ }^{46}$ Por. A. LAmeri, La Traditio Instrumentorum e delle insegne nei riti di ordinazione. Studio storico-liturgico, Roma: Edizioni Liturgiche 1998 s. 43. Na temat nałożenia Ewangeliarza na głowę przyjmującego święcenia biskupie por. W. BARTOCHA, Ksztaltowanie się obrzędów święceń biskupa od Tradycji apostolskiej do Pontyfikatu rzymsko-germańskiego (zarys historycznoliturgiczny), „Seminare” 30 (2011), nr 2, s. 20-21.

${ }^{47}$ Por. B. BotTe, Le rituel d'ordination des Statuta Ecclesiae Antiqua, „Recherches de théologie ancienne et médiévale" 1939, nr 11, s. 231-233.

${ }^{48}$ Konstytucje apostolskie, VIII, 4, 6, w: Synody i kolekcje praw, t. 2, układ i oprac. A. Baron, H. Pietras, przekład S. Kalinowski, Kraków: Wydawnictwo WAM 2007, s. 221* (dalej KA). 
A. Santantoni wyklucza rzymskie pochodzenie tego rytu ze względu na brak dowodów. Jego zdaniem najprawdopodobniej dwie różne tradycje łacińskie, rzymska i galijska, zaczerpnęły ten ryt, każda na własną rękę i niezależnie od siebie, z wielkiej tradycji wschodniej ${ }^{49}$. Natomiast w Rzymie praktyka nakładania Ewangeliarza poświadczona jest w VI wieku. Zwyczaj ten początkowo zarezerwowany była dla święceń biskupich udzielanych papieżowi. Taka sytuacja trwała do X wieku. Dopiero w Ordo Romanus XXXV pojawia się praktyka nakładania Ewangelii w czasie wszystkich święceń biskupich ${ }^{50}$. W przypadku rytu nałożenia księgi Ewangelii w święceniach biskupich, jaki pojawia się w Statuta Ecclesiae Antiqua, nie mamy jeszcze do czynienia z rytem przekazania (consegna), ale po raz pierwszy jak trafnie zauważa Angelo Lameri - pojawia się tutaj element obrzędowy, który towarzyszy i objaśnia, z całym ładunkiem swojej symboliki, nałożenie rąk i modlitwę święceñ ${ }^{51}$.

\section{KONKLUZJE}

Krytyczna analiza zachowanych tekstów źródłowych pod kątem ustalenia genezy, waloru oraz lokalizacji w strukturze liturgii święceń gestu nałożenia rąk $\mathrm{w}$ pierwszych pięciu wiekach istnienia chrześcijaństwa pozwala na sformułowanie następujących wniosków:

- już w czasach Nowego Testamentu nałożenie rąk i modlitwa stanowiły centralne elementy liturgii „święceń”;

- obrzęd nałożenia rąk, zaczerpnięty najprawdopodobniej z praktyk żydowsko-rabinistycznych, stał się w Kościele pierwotnym odrębnym i niezależnym rytem - znakiem widzialnym rzeczywistej mocy Bożej zstępującej na ludzi, którym powierzano urząd we wspólnocie eklezjalnej, i w tym sensie nie ma on swojego odpowiednika w przestrzeni społecznopolitycznej, gdyż święcenia nie dają się zestawić z żadną z wówczas obowiązujących w świecie rzymskim form wprowadzenia na urząd, np. konsula czy pretora ${ }^{52}$;

\footnotetext{
${ }^{49}$ Por. A. SAntantoni, L'ordinazione episcopale s. 139.
}

${ }^{50}$ Ordo $X X X V$ A, nr 8, w: M. Andrieu, Les Ordines Romani du haut moyen age, IV: Les Textes (suite) (Ordines XXXV-XLIX), Leuven: Spicilegium Sacrum Lovaniense 1985, s. 74: „Qua finita, domnus apostolicus elevat ipsum electum, imponens caput eius super altare et duo episcopi nitentes aevangelia tenent super verticem eius...”. Por. W. BARTOCHA, Ksztaltowanie się obrzędów święceń biskupa, s. 21; zob. A. SANTANTONI, L'ordinazione episcopale, s. 138-40.

${ }^{51}$ Por. A. LAMERI, La Traditio Instrumentorum, s. 44.

${ }^{52}$ C. Vogel zauważa, że nie przez wykonanie pierwszego aktu swojego ministerium biskup, prezbiter lub diakon electus czy designatus staje się prawdziwym biskupem, prezbiterem czy dia- 
- na Zachodzie krystalizuje się zasada, zgodnie z którą impositio manuum występuje tylko przy święceniach biskupa, prezbitera i diakonatu, natomiast nie ma nakładania rąk przy tzw. święceniach niższych (np. lektoratu, akolitatu itp.);

- pod tym względem występuje zasadnicza różnica między Zachodem i Wschodem, gdyż w liturgii wschodniej przewiduje się nałożenie rąk dla wszystkich stopni hierarchii kościelnej ${ }^{53}$;

- nałożenie rąk dokonywane przez biskupa wraz z towarzyszącą modlitwą jako rdzeń liturgicznej formy przekazywania władzy „apostołowania” w Kościele nabiera rysu pneumatohagijności, gdyż staje się pasem transmisyjnym dla daru Ducha Świętego;

- wraz z wyodrębnianiem się trójstopniowej hierarchii uwypukla się różnicę co do waloru sakramentalno-ontologicznego gestu nałożenia rąk na kandydata przez wszystkich obecnych biskupów od kolegialnego nakładania rąk prezbiterium (nałożenie rąk przez prezbiterów nie ma charakteru sakramentalnego i nie oznacza przekazania łaski Ducha Świętego, lecz jest wyrażeniem solidarności z działaniem biskupa oraz znakiem włączenia nowego członka do ordo presbyterorum).

\section{BIBLIOGRAFIA}

BARTOCHA Waldemar, Kształtowanie się obrzędów święceń biskupa od Tradycji apostolskiej do Pontyfikatu rzymsko-germańskiego (zarys historyczno-liturgiczny), „Seminare” 30 (2011), s. $17-27$.

konem, tak jak to ma miejsce w przypadku konsula czy pretora. Consul designatus przywdziewa samodzielnie swój oficjalny strój, udaje się na Kapitol, zajmuje miejsce na krześle kurialnym i przez to wprowadzenie na urząd staje się rzeczywiście konsulem. Podobnie praetor designatus idzie do sądu, zajmuje swoje miejsce, rozstrzyga sprawę prawną i poprzez wykonanie tych czynności staje się pretorem - por. C. Vogel, L'imposition des mains dans les rites d'ordination en Orient et en Occident, s. 72.

${ }^{53} \mathrm{Na}$ Zachodzie przyjmie się wyraźne rozróżnienie na płaszczyźnie terminologicznej między ustanawianiem akolitów, lektorów, wdów bez włożenia na nich rąk oraz ustanawianiem diakonów, prezbiterów i biskupów z włożeniem rąk. W pierwszym przypadku będziemy posługiwać się terminem technicznym instituire, w drugim zaś ordinare. Na Wschodzie nie zostanie to natomiast nigdy do końca precyzyjnie określone, czego świadectwem są Konstytucje apostolskie, powstałe w środowisku judeochrześcijańskim w Antiochii w IV wieku. W dokumencie tym wspomina się również o nałożeniu rąk przy ordynacji diakonisy (KA VIII, 19,2), ustanawianiu subdiakona (KA VIII, 21,2), lektora (KA VIII, 22,2). We wszystkich tych przypadkach, podobnie

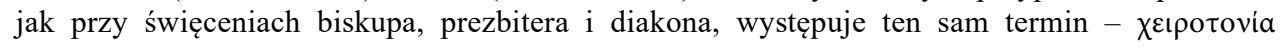
[cheirotonía]. Nałożenie rąk jest natomiast zakazane, jeśli chodzi o dziewicę (KA VIII, 24,2), wdowę (KA VIII, 25,2) oraz egzorcystę (VIII, 26, 2-3), ponieważ ich się „nie ustanawia”. 
Bradshaw Paul F., Rites of Ordination. Their History and Theology, Collegeville: Order of Saint Benedict 2014.

Cavalli Giampaolo, L'imposizione delle mani della tradizione della Chiesa Latina. Un rito che qualifica il sacramento, Roma: Edizioni Antonianum 1999.

CoYle John Kevin, The Laying on of Hands as Conferral of the Spirit: Some Problems and a Possible Solution, w: Studia Patristica, t. XIII/2: Papers of the 1983 Oxford Patristics Conference Critica, Classica, Ascetica, Liturgica, red. Elizabeth A. Livingstone, Leuven: Peeters Publishers 1989, s. 339-353.

GALtIER Paul, Imposition des mains, w: Dictionnaire de théologie catholique, red. Alfred Vacant, Eugène Mangenot, t. 7/2, Paris: Librairie Letouzey 1923, kol. 1302-1425.

KONECKI Krzysztof, Nałożenie rąk w odnowionych obrzędach święceń, w: Ante Deum stantes, red. Stefan Koperek, Robert Tyrała, Kraków: Wydawnictwo UNUM 2002, s. 293-300.

KwiatKowski Dariusz, Obrzędy święceń prezbiteratu do X wieku, w: Studia liturgiczne, t. 7: Prezbiterzy w Kościele do Soboru Trydenckiego. Liturgia święceń, teologia, ministerium, red. Czesław Krakowiak, Waldemar Pałęcki, Lublin: Towarzystwo Naukowe KUL 2011, s. 19-30.

LAMERI Angelo, La Traditio Instrumentorum e delle insigne nei riti di ordinazione. Studio storicoliturgico, Roma: Edizioni Liturgiche 1998.

PAternoster Mauro, L'imposizione delle mani nella chiesa primitiva. Rassegna delle testimonianze bibliche, patristiche e liturgiche fino al secolo quinto, Roma: Edizioni Liturgiche 1983.

SANTANTONI Antonio, L'ordinazione episcopale. Storia e teologia dei riti dell'ordinazione nelle antiche liturgie dell'Occidente, Roma: Editrice Anselmiana 1976.

SAntantoni Antonio, PARenti Stefano, Gli ordini sacri e i ministeri, w: Scientia liturgica. Manuale di liturgia, t. 4: Sacramenti e sacramentali, red. Anscar J. Chupungco, Casale Monferrato: Piemme 1998, s. 209-266.

Vogel Cyrille, L'imposition des mains dans les rites d'ordination en Orient et en Occident, „La Maison-Dieu" 1970, nr 102, s. 52-72.

\title{
NAŁOŻENIE RĄK W LITURGII ŚWIĘCEŃ W PIERWSZYM TYSIĄCLECIU (CZĘŚĆ I: STAROŻYTNOŚĆ CHRZEŚCIJAŃSKA)
}

\author{
Streszczenie
}

Nałożenie rąk należy, obok modlitwy święceń, do istoty obrzędów święceń biskupa, prezbiterów i diakonów. Gest ten występuje w ścisłej korelacji z następującą po nim modlitwą święceń. Modlitwa błogosławieństwa i prośby określa jego znaczenie. Posoborowa reforma liturgiczna obrzędów święceń na nowo wyakcentowała obrzęd nałożenia rąk, przywracając mu w ten sposób pierwotne znaczenie. Celem artykułu jest ukazanie genezy i sensu teologicznego gestu nałożenia rąk, jak również jego miejsca w strukturze celebracji święceń w pierwszym tysiącleciu. Gest nałożenia rąk ma korzenie biblijne. W Nowym Testamencie nałożenie rąk na kandydata oznaczało przekazanie mu charyzmatu właściwego dla danego urzędu. W schemacie obrzędowym zawartym w Tradycji apostolskiej gestu nałożenia rąk używa się do powierzenia urzędu biskupa, prezbitera i diakona. Odgrywa on centralną rolę w dynamice celebracji święceń.

Słowa kluczowe: nałożenie rąk; święcenia; Duch Święty; biskup; prezbiter; diakon. 